\title{
Cooperative Learning in Basic Mathematics Lesson Study Activity
}

\author{
Dyah Triwahyuningtyas*, Nyamik Rahayu Sesanti \\ Primary School Teacher Department, Faculty of Education \\ Universitas PGRI Kanjuruhan Malang \\ Malang, Indonesia \\ *dyahtriwahyu@unikama.ac.id,nyamik@unikama.ac.id
}

\begin{abstract}
Lesson Study is a learning activity that has been implemented in various countries as well as at the school institution level. Innovative implementation of lesson study activities can be collaborated with cooperative learning. The purpose of this study is to describe Lesson Study activities in basic mathematics through a cooperative learning model to build student learning activity. Cooperative learning in lesson study activities was described qualitatively. The qualitative data on learning activeness were obtained from 31 respondents. Lesson Study activities in cooperative learning that is able to foster and encourage student activity was by providing math problems, forming groups, giving project assignments and working on presentations. The results of the implementation of cooperative learning in lesson study activities show that students are active in the discussions, encouraged to ask questions and able to work together in doing project assignments. Based on these results, it shows that cooperative learning in lesson study activities can build 80 percent of students' active learning.
\end{abstract}

Keywords-active involvement, cooperative, lesson study, basic mathematics

\section{INTRODUCTION}

Lesson Study is a program to improve the quality of learning carried out by lecturers collaboratively, with the steps of setting goals, analysing curriculum, planning lessons, implementing learning and observing implementation, conducting question and answer session related to the issues of learning process, and reflecting on the next lesson plan $[1,2]$. This is in accordance with the statement [3] based on the principles of mutual collaboration and developing learning communities [4]. Lesson study is a model of coaching (or training) for a collaborative-centred teaching profession [5] which is used to support and provide advice to the professional development of lecturers. Therefore, the implementation of lesson study focuses on students and achievement [6,7] the learning stage in the classroom which has an impact on achieving learning goals and objectives [8].

Lesson Study is a lecturer coaching program that has been carried out in the Primary School Teacher study program through collaborative learning and reflection linking theory and practice $[9,10]$ to develop, discuss, teach and reflect on a lesson
[11]. The implementation of structured learning [11,12], identifies from the knowledge of the pedagogical [13] Therefore, collaborative learning between students and lecturers supports learning innovation [14] opens opportunities for lecturers to observe and understand student learning [15]. This lesson study is created to think independently and deepen learning [16], incorporate conceptual mathematical creativity [17] which are obtained by sharing ideas. Cooperation tends to result in learning process [18] and the support of mathematical resource instruments will find significant impacts on lecturers as well as students [19]. Lesson studies are expected to increase the professional competence of lecturers and student achievement. Therefore, lesson study is an effective solution to overcome learning problems.

Conditions in the field showed that there are still some lecturers who do not understand or pay less attention to students' learning outcomes, learning strategies and methods as well as proper assessment methods. There is an expectation that face-to-face learning once a week has carried out learning according to the requirements of the existing rules, since the comprehension of successful teaching approaches is based on the frequency of face-to-face meetings in the class, not based on conduciveness and learning achievement. In this learning activity, Lesson Study consists of several learning models, specifically, Two Stay Two Stray type of cooperative learning model, the TGT learning model and the NHT learning model. The model is carried out by teaching students to acknowledge the perspectives of others in a cooperative manner oriented towards a mutually beneficial atmosphere between students [20].

Two Stay Two Stray learning model helps students to actively learn and trains students to socialize well. The Two Stay Two Stray type of cooperative learning model is a cooperative learning technique by sharing advice and information, helping to solve problems and encouraging each other to achieve [21]. TGT is a cooperative learning model using tournaments per group to facilitate solving math problems [22]. The NHT Learning Model, the purpose of calling this student number is that students do not depend on solving problems on high-ability students. This NHT learning model can help students with low academic abilities assisted by 
friends who have high abilities as a reference and motivation in groups [23].

\section{METHODS}

This research is a classroom action research using learning system development procedures that are applied in the lesson study. The research subjects are 31 PGSD students 2015 on Universitas Kanjuruhan Malang. This research described a lesson study in Basic Mathematics course in Primary School Department. It was carried out by three expert of Mathematics development team who teach Basic Mathematics course. The research was conducted every three weeks with a different model lecturer for each open class activity. This qualitative research analysis employed the theory of Mils and Huberman's analysis techniques. This analysis technique basically consisted of three components: data reduction, data presentation, and drawing and verifying conclusions [24]. The steps in the data reduction component was editing, grouping and summarizing data. The second component was the presentation of data. The last component was drawing and testing conclusions. The lesson study activities in the PGSD study program in the Basic Mathematics course consisted of several stages: (1) Planning Stage (Plan). At this stage, it is related to the learning plan that will be conveyed to students. (2) Implementation Stage (Do). (3) Reflection Stage (See), (4) Analysis of the constraints in implementing the Lesson Study activities and (5) Recommendations for the implementation of the Lesson Study of the need for additional facilities and infrastructure in the lesson study processs.

\section{RESULTS AND DISCUSSION}

The implementation of Lesson Study activities has been carried out in the Basic Mathematics course from cycle I-VI according to lesson plan. Lesson Study stages in each cycle began with planning, that was compiling a lesson plan made by focusing on emphasizing the importance of cooperation and students' critical thinking skills. The next activity was continued by implementation (do). It began with giving initial problems to students. Furthermore, it was followed by discussions and presentations. The presentations activities were accompanied by games. This game activity was proven to increase learning activity in classroom. This is in line with Juwita [25] stating that students will enjoy the atmosphere of the tournament, because they compete with groups having equal abilities, making TGT feels fairer than the competition in traditional learning in general. From the explanation of the implementation activities (do) it has been planned to use the TGT model in accordance with the TGT stages [26]. The last activity after the learning process was reflection (see). It aimed at evaluating student activities during learning.

The explanation of each cycle is as follows: in cycle I about (the topic of set 1) the application of learning was carried out using the Teams Games Tournament (TGT) model. The stages were carried out in cycle I, specifically: (1) The plan stage began with compiling a learning plan that will be implemented based on the initial data on the condition of the students submitted by the lecturer who teaches Basic Mathematics courses. (2) Then, the do stage or the implementation stage of learning began by opening the lesson with problem. It was followed by students' discussion and then students were presenting. The next activity was the tournament, then the model lecturer concurrently with the students drew conclusions and give motivation. (3) At the see stage, the implementation team of lesson study reflected the activities conducted at the do stage.

In cycle II regarding (the topic of Set 2), the application of learning was carried out using the Teams Games Tournament (TGT) model. The stages were carried out in cycle II, specifically (1) The plan stage began with compiling a design focusing on emphasizing the importance of understanding the material and student cooperation. (2) The do stage or the implementation stage of learning began by opening the lesson by giving problems. Each group began to discuss the problem and then presented it to the class. Furthermore, the model lecturer along with students provided conclusions about the learning that has been learned. (3) In the see stage, the lesson study implementation team discussed all activities that have been carried out at the do stage.

In cycle III about (Relationship and Function 1), the application of learning was carried out using the Number Head Together (NHT) model. (1) The plan stage began with compiling a lesson plan that focuses on emphasizing the importance of students' ability to understand the material. (2) The do stage or the implementation stage of learning was started by opening the lesson by giving problems by the model lecturer then discussing After the students have completed the discussion and presentation, then the students called the numbers in the game (NHT). At the end of the activity, the model lecturer along with the students provided conclusions and motivation. (3) In the see stage, the implementation team for lesson study evaluation was carried out based on the activities at the do stage.

In cycle IV about (Relationship and Function 2), the application of learning was carried out using the Number Head Together (NHT) model. The stages carried out in cycle VI were (1) The plan stage was started by compiling a learning design focused on problem-solving activities by each student to determine the student's understanding of the material. (2) The do stage or the implementation stage of learning was started by opening lessons, discussing the problem by entering the $\mathrm{x}$ member into a linear function and the quadratic function which was known. After the students finish the discussion, then, it was followed by the presentations. Furthermore, students provided conclusions and motivation about the lessons learned today. (3) At the see stage, the lesson study implementation team evaluated the implementation stage. Based on the results of the lesson study implementation team discussion, in this fourth cycle, 90 percent of students were active in group discussions and all students were involved in solving problems or questions given by the lecturer. 
Based on the description of the Lesson Study activities that have been implemented, the stages that were conducted planning (plan), implementation (do) and reflection (see) were in line with the results discovered by Newton [27]. From the results of observations and reflections on the implementation of Lesson Study activities, it can be concluded that student active involvement during the learning in Lesson Study activities from cycles I - VI has increased. From the beginning, the majority of active student activity was dominated by highability students. As the learning process underwent, all students took an active role to work on problem-solving of Basic mathematics. By giving non-routine questions, it can also improve students' critical thinking skills in solving problems. This is in line with Ramadiana et al [28], where the active involvement of students in the learning process in the Mathematics Teaching Program Planning and Development course by using a cooperative learning model is significant to increase creativity and understanding of concepts in learning mathematics.

\section{CONCLUSION}

Based on the implementation of the learning that has been carried out, it can be concluded that: (1) Planning for Lesson Study activities begins with compiling a plan for learning process (Lesson Plan) which will be carried out based on initial data on student conditions submitted by lecturers who teach Basic Mathematics courses. (2) The implementation of Lesson Study activities conducted in the Basic Mathematics course generally runs smoothly according to planning designed, specifically Plan, Do and See. (3) The results of observation and reflection on the implementation of Lesson Study activities show that (a) the student active involvement in Lesson Study activities from cycle I - VI has increased. From the beginning, the majority of active student activity was dominated by highability students. As the learning process underwent, all students took an active role to work on problem-solving in Basic Mathematics course. (b) By giving non-routine questions, it can improve students' critical thinking skills in solving problems. (c) Students are increasingly responsible for collaborating and completing tasks in Basic Mathematics courses.

\section{REFERENCES}

[1] A. Murata, "Lesson study in preservice elementary mathematics methods courses: Connecting emerging practice and understanding," Lesson Study Research and Practice in Mathematics Education: Learning Together. pp. 103-116, 2011.

[2] A. Murata, "Making connections among student learning, content, and teaching: Teacher talk paths in elementary mathematics lesson study," J. Res. Math. Educ., vol. 43, no. 5, pp. 616-650, 2012.

[3] K. Kostas, R. Galini and M. Maria, "The Practicum in Pre - Service Teachers' Education in Greece: The Case of Lesson Study," Procedia Soc. Behav. Sci., vol. 152, no. October, pp. 808-812, 2014.

[4] K. Matanluk, K. Johari and O. Matanluk, "The Perception of Teachers and Students toward Lesson Study Implementation at Rural School of Sabah: A Pilot Study," Procedia - Soc. Behav. Sci., vol. 90, pp. 245$250,2013$.
[5] R. Bjuland, "Lesson study in teacher education: Learning from a challenging case," Teach. Teach. Educ., vol. 52, pp. 83-90, 2015

[6] Z. Bradshaw, "Developing problem-solving skills in mathematics: a lesson study,” Int. J. Lesson Learn. Stud., vol. 6, no. 1, pp. 32-44, 2017.

[7] M. Isoda, "Lesson Study : Problem Solving Approaches in Mathematics Education as a Japanese Experience," vol. 8, pp. 17-27, 2010.

[8] C. Fernandez, "Learning from Japanese approaches to professional development: The case of lesson study," J. Teach. Educ., vol. 53, no. 5, pp. 393-405, 2002.

[9] R. Galini and K. Kostas, "Reflection of Pre-service Teachers in a Tabletop Exercise of Lesson Study during their Practicum," Procedia Soc. Behav. Sci., vol. 152, pp. 868-873, 2014.

[10] C.S. Lim, L.K. Kor and H.M. Chia, "Revitalising mathematics classroom teaching through Lesson Study (LS): a Malaysian case study," ZDM - Math. Educ., vol. 48, no. 4, pp. 485-499, 2016.

[11] A.M. Leavy and M. Hourigan, "Using lesson study to support knowledge development in initial teacher education: Insights from early number classrooms," Teach. Teach. Educ., vol. 57, pp. 161-175, 2016.

[12] S. Groves, B. Doig, C. Vale and W. Widjaja, "Critical factors in the adaptation and implementation of Japanese Lesson Study in the Australian context," ZDM - Math. Educ., vol. 48, no. 4, pp. 501-512, 2016

[13] A.N. Shuilleabhain, "Developing mathematics teachers' pedagogical content knowledge in lesson study: Case study findings,” Int. J. Lesson Learn. Stud., vol. 5, no. 3, pp. 212-226, 2016.

[14] W. Kanauan and N. Inprasitha, "Collaboration between Inservice Teachers and Student Intern in Thai Lesson Study," Procedia - Soc. Behav. Sci., vol. 116, pp. 28-32, 2014

[15] M. Inprasitha and N. Changsri, "Teachers' Beliefs about Teaching Practices in the Context of Lesson Study and Open Approach," Procedia - Soc. Behav. Sci., vol. 116, pp. 4637-4642, 2014

[16] L.S. Lomibao, "Enhancing mathematics teachers' quality through Lesson Study," Springerplus, vol. 5, no. 1, 2016.

[17] E.M. Schoevers, P.P.M. Leseman, E.M. Slot, A. Bakker, R. Keijzer and E. H. Kroesbergen, "Promoting pupils' creative thinking in primary school mathematics: A case study," Think. Ski. Creat., vol. 31, no. February, pp. 323-334, 2019.

[18] P. Warwick, "Connecting observations of student and teacher learning: an examination of dialogic processes in Lesson Study discussions in mathematics," ZDM - Math. Educ., vol. 48, no. 4, pp. 555-569, 2016

[19] A. Takahashi, "Collaborative lesson research: maximizing the impact of lesson study," ZDM - Math. Educ., vol. 48, no. 4, pp. 513-526, 2016

[20] O. Risti, S. Haryani and E. Handoyo, "The Effectiveness of the Two Stay Two Stray Model using Pocket Number Media in Social Sciences Subjects," Journal of Primary Education, vol. 8, no. 6, pp. 328-333, 2019.

[21] A. Saputra, "Use Of Two Stay Two Stray Strategy In Teaching Reading," English Educ. J., vol. 7, no. 2, pp. 219-232, 2016.

[22] A. Veloo and S. Chairhany, "Fostering Students' Attitudes and Achievement in Probability Using Teams-games-tournaments," Procedia - Soc. Behav. Sci., vol. 93, pp. 59-64, 2013.

[23] B. Sutipnyo and M. Mosik, "The Use of Numbered Heads Together (NHT) Learning Model with Science, Environment, Technology, Society (SETS) Approach to Improve Student Learning Motivation of Senior High School," J. Pendidik. Fis. Indones., vol. 14, no. 1, pp. 26 31, 2018.

[24] G. Hervas and J.L. Medina, "Key components of lesson study from the perspective of complexity: a theoretical analysis," Teach. Teach. Theory Pract., vol. 26, no. 1, pp. 118-128, 2020.

[25] L. Juwita, N.P.W.P. Sari, and Y. Septianingrum, "The Effect of Team Game Tournament (TGT) Cooperative Learning Method Application Towards Learning Motivation and Achievement," Indones. Nurs. J. Educ. Clin., vol. 2, no. 2, p. 154, 2017. 
[26] H. Yunanda, L. Advinda and R. Sumarmin, "Effects of Cooperative Learning Model Type Games Teams Tournament ( TGT ) and Entry Behavior Student to Learning Competence Class XI IPA Senior High School 1 Lengayang,” Int. J. Progress. Sci. Technol., vol. 6, no. 2, pp. 329-339, 2018 .
[27] X. Newton, "Building undergraduate STEM majors' capacity for delivering inquiry-based mathematics and science lessons: An exploratory evaluation study,” Stud. Educ. Eval., vol. 64, 2020.

[28] A. Ramadiana, A. In'am, and A.S. Kusumawardana, "The Effect of Cooperative Learning Type Teams Games Tournament (TGT) on Creativity and Comprehension the Student's Concept in Mathematics Learning," Math. Educ. J., vol. 3, no. 1, p. 17, 2019. 